\title{
Ferulate Anion Intercalated into Zn/Al Layered Double Hydroxide: A Promising Intercalation Compound for Inhibition of Leishmania (L.) amazonensis
}

\author{
Robson Sousa, ${ }^{a}$ Bruno J. M. da Silva ${ }^{b, c}$ Amarilis A. Dias, ${ }^{b}$ Carla C. F. Meneses, ${ }^{a}$ \\ Beatriz A. Bentes, ${ }^{a}$ Edilene O. Silva, ${ }^{*, b, c}$ Cláudio M. R. Remédios, ${ }^{a}$ Waldeci P. Feio, ${ }^{a}$ \\ Olivier Masson, ${ }^{d}$ Cláudio N. Alves, ${ }^{a}$ Mara M. S. P. Arruda ${ }^{a}$ and Jerônimo Lameira ${ }^{\circledR} * a$ \\ aInstituto de Ciências Exatas e Naturais, Universidade Federal do Pará, 66075-110 Belém-PA, Brazil \\ ${ }^{b}$ Instituto de Ciências Biológicas, Universidade Federal do Pará, 66075-110 Belém-PA, Brazil \\ 'Instituto Nacional de Ciência e Tecnologia de Biologia Estrutural e Bioimagem, \\ 21941-902 Rio de Janeiro-RJ, Brazil \\ ${ }^{d}$ Laboratoire Science des Procédés Céramiques et de Traitements de Surface (SPCTS), \\ Université de Limoges-CNRS UMR 7315, Centre Européen de la Céramique, Limoges, France
}

\begin{abstract}
Ferulic acid (FERH) is known to exert leishmanicidal action against Leishmania (Leishmania) amazonensis. In this study, the ferulate anion $\left(\mathrm{FER}^{-}\right)$was intercalated into a layered double hydroxide (LDH) for FER- delivery during an antileishmania in vitro test. The $\mathrm{LDH}^{-\mathrm{FER}^{-}}$ intercalation compound was prepared by coprecipitation and was characterized by X-ray powder diffraction, thermogravimetry, UV-Vis, infrared, and Raman spectroscopy analyses. Leishmania (L.) amazonensis in vitro assays were conducted to assess the LDH-FER ${ }^{-}$potential. $\mathrm{LDH}_{-\mathrm{FER}^{-}}$was found to promote a dose-dependent reduction of $L$. $(L$. ) amazonensis amastigotes (intracellular form, half maximal inhibitory concentration $\left(\mathrm{IC}_{50}\right)=1.78 \mu \mathrm{g} \mathrm{mL}^{-1}$ ) without exerting a deleterious effect on the host macrophages (medium cytotoxic concentration $\left(\mathrm{CC}_{50}\right)=212.61 \mu \mathrm{g} \mathrm{mL}^{-1}$ and selectivity index $=119.4$ ). LDH-FER $^{-}$was found to be an effective inhibitor of the amastigote form of $L$. (L.) amazonensis, suggesting that LDH-FER ${ }^{-}$was able to deliver FER ${ }^{-}$inside the parasitophorous vacuoles where the $\mathrm{pH}$ is more acidic.
\end{abstract}

Keywords: ferulic acid (FERH), intercalation, LDH-FER- intercalation compound, antileishmanial activity

\section{Introduction}

Leishmaniasis is a parasitic disease endemic to American, African, Asian and southern European countries. ${ }^{1}$ More than 350 million individuals in 98 countries are at risk of being infected with this neglected tropical disease, especially in developing countries, such as in Latin America, where 11 different dermotropic species are known that can affect humans. ${ }^{2}$ Leishmania (Leishmania) amazonensis is responsible for causing the most severe form of leishmaniasis, the diffuse (anergic) cutaneous leishmaniasis (DCL). This parasite induces Th1/Th2 CD4+ cell profiles, which silence the microbicidal responses of macrophages (host cell) creating a favorable environment for infection. ${ }^{3}$ Furthermore, even after receiving treatment, this cell profile cannot be reversed in patients. ${ }^{4,5}$

*e-mail: edilene@ufpa.br; lameira@ufpa.br
The World Health Organization (WHO) recommends the use of chemotherapy for this disease as it has proven to be one of the most effective treatments. Meglumine antimoniate (glucantime ${ }^{\circledR}$ ), miltefosine, and amphotericin B (AMP-B) are examples of chemotherapeutics used to treat leishmaniasis. ${ }^{6}$ Nevertheless, toxic effects are reported for all of these compounds and they presented limited efficacy as parasite resistance becomes more prevalent. Therefore, the development of new antileishmanial inhibitors with lowest toxicity is needed. Compounds isolated from microorganisms ${ }^{7}$ and medicinal plants have also demonstrated leishmanicidal activity. ${ }^{8-14}$ Recently, the antileishmanial and cytotoxic activities of five natural compounds from Pluchea carolinensis were evaluated in vitro and in vivo. Among these natural products, ferulic acid (FERH; 4-hydroxy-3-methoxycinnamic acid) has been reported to be a potential inhibitor of Leishmania tropica promastigotes. ${ }^{15}$ FERH was one of the most active 
compounds against intracellular amastigotes form of L. (L.) amazonensis. ${ }^{16}$ However, FERH has presented cytotoxicity on noninfected peritoneal macrophages ${ }^{16}$ and its small cellular uptake limits clinical applications. ${ }^{17}$

Layered double hydroxides (LDH) are inorganic nanoparticles with excellent features as nanocarriers in drug delivery systems. ${ }^{18-20}$ These nanoparticles have the potential to play an important role in healthcare..$^{21} \mathrm{LDH}$ also known as anionic clay have become one of the most promising candidates for various biological applications due to their high cellular uptake, non-immunogenic response, and low toxicity. ${ }^{22} \mathrm{LDH}$ comprise a large family of anionic clays with great potential in materials science and technology ${ }^{23}$ due to their versatile structures, intercalation properties, wide range of applications, good biocompatibility, improved drug solubility, ${ }^{24}$ and potential for target delivery. ${ }^{25}$

LDH are structurally composed of layers with positive charges that are electrically neutral thanks to the presence of anions that, together with water molecules, promote the characteristic stacking of layers observed in these structures. ${ }^{26}$ The general chemical formula of this class of inorganic materials is: ${ }^{27}$

$$
\left[\mathrm{M}_{1-\mathrm{x}}^{\mathrm{II}} \mathrm{M}_{\mathrm{x}}^{\mathrm{III}}(\mathrm{OH})_{2}\right]^{\mathrm{x}+}\left(\mathrm{A}^{\mathrm{n}-}\right)_{\mathrm{x} / \mathrm{n}} \cdot \mathrm{zH}_{2} \mathrm{O}
$$

where $\mathrm{A}^{\mathrm{n}-}$ is an exchangeable inorganic or organic anion, often a carbonate and nitrate, that compensates for the positively charged hydroxide brucite-type layers; $\mathrm{x}$ refers to the molar fraction $\mathrm{M}^{3+} /\left(\mathrm{M}^{2+}+\mathrm{M}^{3+}\right)$, usually $(0.2 \leq \mathrm{x} \leq 0.4),{ }^{28}$ and $\mathrm{z}$ is the amount of hydration water molecules.

Previous reports have focused on the synthesis of LDH-FER- hybrids, ${ }^{29-32}$ as well as on the study of their drug release properties, using various methods. Also, the coprecipitation method was used recently to intercalate ibuprofen into layered double hydroxides (LDH-IBU) and performed in vivo assays of the analgesic activity using male Swiss mice. ${ }^{33}$ In this work, the ferulate anion (negatively charged; $\mathrm{FER}^{-}$) was intercalated by coprecipitation method into a biocompatible $\mathrm{Zn} / \mathrm{Al}$ layered double hydroxide $\mathrm{LDH}\left(\mathrm{Zn} / \mathrm{Al}-\mathrm{NO}_{3}{ }^{-}\right)$. In addition, the effect by which the FER $^{-}$released from LDH-FER- intercalation compound acts as a leishmanicidal agent against $L$. (L.) amazonensis was investigated.

\section{Experimental}

\section{Chemicals and reagents}

All reagents were purchased from Sigma-Aldrich: ferulic acid $(99 \%)$, zinc nitrate hexahydrate $\left(\mathrm{Zn}\left(\mathrm{NO}_{3}\right)_{2} \cdot 6 \mathrm{H}_{2} \mathrm{O}\right.$;
98\%), aluminum nitrate nonahydrate $\left(\mathrm{Al}\left(\mathrm{NO}_{3}\right)_{3} \cdot 9 \mathrm{H}_{2} \mathrm{O}\right.$; 98\%), metallic sodium ( $\mathrm{Na}(\mathrm{s}) ; 99.9 \%)$, ethyl alcohol $\left(\mathrm{CH}_{3} \mathrm{CH}_{2} \mathrm{OH} ; 99.5 \%\right)$, dimethyl sulfoxide (DMSO, $\left.\left(\mathrm{CH}_{3}\right)_{2} \mathrm{SO} ; \geq 99.7 \%\right)$, and phosphate buffer ( $\mathrm{pH} 7.40 \pm 0.02$; $98 \%$ ). Deionized water was decarbonated prior to synthesis.

\section{Preparation of pristine $\mathrm{LDH}\left(\mathrm{Zn} / \mathrm{Al}-\mathrm{NO}_{3}^{-}\right)$}

The coprecipitation method was used in the synthesis of the pure $\mathrm{LDH}\left(\mathrm{Zn} / \mathrm{Al}-\mathrm{NO}_{3}^{-}\right)$. A mixed aqueous solution $(50.0 \mathrm{~mL})$ containing $13.8507 \mathrm{~g}(46.56 \mathrm{mmol})$ of $\mathrm{Zn}\left(\mathrm{NO}_{3}\right)_{2} \cdot 6 \mathrm{H}_{2} \mathrm{O}$ and $8.6901 \mathrm{~g}(23.16 \mathrm{mmol})$ of $\mathrm{Al}\left(\mathrm{NO}_{3}\right)_{3} \cdot 9 \mathrm{H}_{2} \mathrm{O}$ was added dropwise to $200.0 \mathrm{~mL}$ of deionized and decarbonated water, of which the $\mathrm{pH}$ was adjusted to 9.57 , under stirring and in a nitrogen atmosphere. During the procedure, the value of the $\mathrm{pH}$ was maintained approximately constant ( $\mathrm{pH} 9.47$ ) by the continuous addition of $2.0 \mathrm{~mol} \mathrm{~L}^{-1}$ $\mathrm{NaOH}$ solution. The resulting precipitate was kept under $\mathrm{N}_{2}$ gas flow at room temperature with stirring for $72 \mathrm{~h}$. The solid was then isolated by centrifugation and washed thoroughly with water $\left(50^{\circ} \mathrm{C}\right)$ and dried in a vacuum desiccator.

Intercalation of $\mathrm{FER}^{-}$into $\mathrm{LDH}\left(\mathrm{Zn} / \mathrm{Al}-\mathrm{NO}_{3}^{-}\right)$

Similarly, the coprecipitation method was used for intercalation of FER- into $\mathrm{LDH}\left(\mathrm{Zn} / \mathrm{Al}-\mathrm{NO}_{3}^{-}\right)$. Here, $25.0 \mathrm{~mL}$ of ethoxide solution $\left(\mathrm{EtO}^{-}\right)$obtained from a mixture of $0.2576 \mathrm{~g}\left(11.20 \mathrm{mmol} \mathrm{L}^{-1}\right)$ of the sodium metal, ethanol, and $\operatorname{DMSO}\left(4: 1 \mathrm{v} \mathrm{v}^{-1}\right)$ were added to a three-neck flask containing $6.00439 \mathrm{~g}$ (30.92 mmol) of ferulic acid (FERH), producing sodium ferulate salt $\left(\mathrm{FER}^{-} \mathrm{Na}^{+}\right)$as an intense red solution. After a few minutes, a mixed aqueous solution $(25.0 \mathrm{~mL})$ containing $3.7061 \mathrm{~g}(12.458 \mathrm{mmol})$ of $\mathrm{Zn}\left(\mathrm{NO}_{3}\right)_{2} \cdot 6 \mathrm{H}_{2} \mathrm{O}$ and $2.3294 \mathrm{~g}(6.209 \mathrm{mmol})$ of $\mathrm{Al}\left(\mathrm{NO}_{3}\right)_{3} \cdot 9 \mathrm{H}_{2} \mathrm{O}(\mathrm{Zn} / \mathrm{Al}=2.0)$ was slowly added to the FER $\mathrm{Na}^{+}$solution. To ensure the dissolution of FERH, the initial $\mathrm{pH}$ was adjusted to $9.53 \mathrm{using}$ $2.0 \mathrm{~mol} \mathrm{~L}^{-1} \mathrm{NaOH}$ solution. The addition was performed in the dark and under vigorous stirring in a nitrogen atmosphere to protect the reagents from light and oxygen. During the procedure, the $\mathrm{pH}$ was maintained approximately constant (final $\mathrm{pH} 9.51$ ) by the continuous addition of a $2.0 \mathrm{~mol} \mathrm{~L}^{-1}$ $\mathrm{NaOH}$ solution. The resulting dispersion (final $\mathrm{pH}$ 9.51) was kept in the dark and under $\mathrm{N}_{2}$ gas flow and stirred at room temperature for $72 \mathrm{~h}$. The solid was isolated by centrifugation and washed thoroughly three times with aqueous ethanol solution (50 vol\%), and then dried in a vacuum desiccator.

\section{Sample characterization}

Characterization of the samples was performed by X-ray diffraction (XRD), and the composition of the samples was 
determined by inductively coupled plasma (ICP) analysis, differential thermal analysis (DTA), thermogravimetric analysis (TGA) and UV-Vis spectroscopy. Fourier transform infrared (FTIR) spectra, Raman spectra, and micrographs for the powder morphologies were obtained using scanning electron microscopy (SEM). The XRD diffraction patterns of the samples were collected from 2 to $80^{\circ}(2 \theta)$ with a step of $0.04^{\circ}$ and an effective acquisition time of $2.8 \mathrm{~s}$ per step using a Bruker D8 Advance diffractometer with BraggBrentano geometry, LynxEye position sensitive detector (PSD) detector, and $\mathrm{CuK} \alpha$ radiation $(\lambda=1.5418 \AA$ ). The XRD diffraction pattern was measured by the Peakoc software $^{34}$ using a split pseudo-Voigt function ${ }^{35}$ to fit the experimental profiles. For the ICP measurements, $1 \mathrm{mg}$ of both pristine LDH and LDH-FER- samples were dissolved in an aqua regia solution. The aliquots were left to cool after which $1 \mathrm{~mL}$ of aliquot was diluted with $9 \mathrm{~mL}$ of deionized water. These were then analyzed on a Varian ICP optical emission spectrometer (OES) to quantify the amount of $\mathrm{Zn}$ and $\mathrm{Al}$ present. The calibration was carried out using a multi-element standard (ICP grade). Each sample was measured three times and the average ICP value was recorded. FTIR spectra of the powder samples were scanned $\left(400-4000 \mathrm{~cm}^{-1}\right)$ on a Bruker Vertex 70v spectrophotometer with a resolution of $2 \mathrm{~cm}^{-1}$. Each spectrum is the average of 100 successive scans. Raman spectra were recorded on a Jobin Yvon T64000 spectrophotometer on raw powder samples using a laser of $1064 \mathrm{~nm}$, with an exposure time of $32 \mathrm{~s}$ and a power of $100 \mathrm{~mW}$. The thermogravimetric analyses were performed using a Shimadzu DTG-60AH instrument. The analyses were carried out from 25 to $1000{ }^{\circ} \mathrm{C}$ at a heating rate of $10{ }^{\circ} \mathrm{C} \mathrm{min}^{-1}$ in flowing nitrogen gas $\left(50 \mathrm{~mL} \mathrm{~min}^{-1}\right)$. Micrographs of the powder morphologies were obtained using a Tescan VEGA3 SEM with an accelerating voltage of $10 \mathrm{kV}$. In addition, solid state UV-Vis spectra for ferulic acid (FERH) and LDH-FER ${ }^{-}$ powder were obtained in a range from 200 to $500 \mathrm{~nm}$ with $\mathrm{BaSO}_{4}$ background by using a Shimadzu UV-2600 UV-Vis spectroscope. Finally, $\mathrm{FER}^{-}$quantification was performed after the destruction of the LDH-FER ${ }^{-}$structure in an acidic medium. Measurements were carried out using a Shimadzu UV-2600 UV-Vis spectroscope as described in our previous work. ${ }^{33}$ One milligram of LDH-FER ${ }^{-}$ sample was dissolved in $0.5 \mathrm{~mL}$ of ethanol and $0.5 \mathrm{~mL}$ of $0.1 \mathrm{~mol} \mathrm{~L}^{-1} \mathrm{HCl}$ solution, with a successive dilution using a phosphate buffer at $\mathrm{pH} 7.40 \pm 0.02$ in a $10 \mathrm{~mL}$ volumetric flask, and the amount of FER ${ }^{-}$in the resulting solution was determined by measuring the absorbance at $\lambda_{\max }=310 \mathrm{~nm}$, where previously a calibration curve had been obtained from a series of standard solutions of pure ferulic acid, of which the $\mathrm{pH}$ was adjusted to 7.4.
Antipromastigote viability by 4,5 -dimethylthiazol-2-yl2,5-diphenyltetrazolium bromide (MTT) method

For the antipromastigote assay, promastigotes of L. (L.) amazonensis (MHOM/BR/26361) were obtained from the Leishmaniasis Program Evandro Chagas Institute, maintained at $27{ }^{\circ} \mathrm{C}$ in a Roswell Park Memorial Institute (RPMI) 1640 medium supplemented with $10 \%$ fetal bovine serum (FBS). Promastigotes of $L$. (L.) amazonensis were used in the exponential growth phase and were treated with $10,20,50,100$, and $200 \mu \mathrm{gL}^{-1}$ of LDH-FER ${ }^{-}$for $96 \mathrm{~h}$ at $25^{\circ} \mathrm{C}$, which corresponds to $0.4,0.9,2.1,4.3$ and $8.5 \mu \mathrm{g} \mathrm{mL} \mathrm{L}^{-1}$, taking into consideration only the amount of FER ${ }^{-}$intercalated in LDH. After completing 96 h of treatment, aliquots were harvested, and promastigotes were incubated for $4 \mathrm{~h}$ with $20 \mu \mathrm{L}$ of MTT (stock solution of $2 \mathrm{mg} \mathrm{mL}^{-1}$ ). After incubation, $20 \mu \mathrm{L}$ of DMSO were added for the solubilization of the formazan crystals. The resulting solution was read in a microplate reader (Bio-Rad Model 450 microplate reader) at a wavelength of $570 \mathrm{~nm}$. Promastigotes treated with $0.5 \mu \mathrm{g} \mathrm{mL}-1$ of AMP-B were used as a positive control.

\section{Antiamastigote assay}

The cell line $\mathrm{J} 774$ of mouse macrophages $\left(10^{3}\right.$ cells per plate) was infected with $L$. (L.) amazonensis promastigotes (ratio 1:10) in the stationary growth phase (7 days) for $3 \mathrm{~h}$, in an atmosphere of $5 \% \mathrm{CO}_{2}$ at $34{ }^{\circ} \mathrm{C}$. After $3 \mathrm{~h}$ of incubation, the infected cells were treated for $72 \mathrm{~h}$ with $0.9,2.1$ and $4.3 \mu \mathrm{g} \mathrm{mL}^{-1}$ of FER ${ }^{-}$present in LDH-FER ${ }^{-}$for $72 \mathrm{~h}$. After treatment, the cells were fixed in $4 \%$ paraformaldehyde/ phosphate-buffered saline (PBS) pH 7.2 for $30 \mathrm{~min}$, stained with Giemsa (Sigma), mounted on glass slides, and counted under a Zeiss Axio Scope.A1 microscope. The endocytic index was determined by counting 200 cells per coverslip, as reported by da Silva et al..$^{36}$ The $50 \%$ inhibitory concentration $\left(\mathrm{IC}_{50}\right)$ of promastigote and amastigote forms was determined using SigmaPlot (version 12). ${ }^{37}$ The infected cells treated with AMP-B $\left(0.5 \mu \mathrm{g} \mathrm{mL}^{-1}\right)$ were used as a positive control.

Host cell

The mouse macrophage cell line $\mathrm{J} 774$ was cultured in 96-well plates $\left(10^{3}\right.$ cells per plate) and treated with different concentrations $\left(0.9-17 \mu \mathrm{g} \mathrm{mL}^{-1}\right)$ of FER ${ }^{-}$released from LDH-FER $^{-}$for $72 \mathrm{~h}$ at $34^{\circ} \mathrm{C}$. Cells were then washed twice with PBS pH 7.2 and incubated with $0.5 \mathrm{mg} \mathrm{mL}^{-1}$ MTT for $3 \mathrm{~h}$ at $37{ }^{\circ} \mathrm{C}$, with $5 \% \mathrm{CO}_{2}$, as described in the literature. ${ }^{38}$ The samples were read in a microplate reader 
(Bio-Rad Model 450 microplate reader) at an absorbance of $570 \mathrm{~nm}$. The medium cytotoxic concentration $\left(\mathrm{CC}_{50}\right)$ was determined using SigmaPlot (version 12$)^{37}$ and the selectivity index (SI) was determined by the ratio of $\mathrm{CC}_{50}$ and $\mathrm{IC}_{50}$ of promastigote/amastigote forms. In all the assays, control cells treated with DMSO and LDH were used.

\section{In vitro ferulate anion release}

The release of $\mathrm{FER}^{-}$in vitro was performed as follows: the $\mathrm{LDH}^{-\mathrm{FER}^{-}}$sample $(10 \mathrm{mg})$ was immersed in PBS at pH 5.0 and $7.4(100 \mathrm{~mL})$ with mild shaking at $150 \mathrm{rpm}$; the temperature was maintained at $37 \pm 0.5^{\circ} \mathrm{C}$. An aliquot of $5 \mathrm{~mL}$ was taken from the suspension from time to time to measure the release of ferulate anion into the solution. Aliquots were immediately replaced by an equal volume of PBS at $37 \pm 0.5^{\circ} \mathrm{C}$ to keep the temperature and volume constant. The content of ferulate anion in each aliquot was filtered and measured at an absorbance of $310 \mathrm{~nm}$ using a Shimadzu UV-2600 UV-Vis spectrophotometer at $\lambda_{\max }=310 \mathrm{~nm}$ according to a previously determined calibration curve $\left(y=0.0735, x=0.0902 ; \mathrm{r}^{2}=0.9992\right)$. The percentage released at each time point was expressed as a fraction of the total amount of FER ${ }^{-}$. Drug release was monitored for $10 \mathrm{~h}$, and the amount of FER ${ }^{-}$was obtained by an average of the three determinations, where the data found was within the calibration curve obtained previously.

\section{Results and Discussion}

XRD powder analysis

Figure 1 shows the X-ray powder diffraction (XRPD) patterns of the pristine $\mathrm{LDH}\left(\mathrm{Zn} / \mathrm{Al}-\mathrm{NO}_{3}{ }^{-}\right)^{39}$ and LDH-FER- intercalation compound. The 003 reflection in the LDH-FER $^{-}$intercalation compound is at lower angle (ca. $5.10^{\circ} 2 \theta$ ) compared with that of the pristine LDH sample, suggesting a lattice expansion along the $c$-axis induced by the intercalation of $\mathrm{FER}^{-}$, as has been previously reported. ${ }^{32,39-41}$ In Figure 1, the pattern of the LDH-FER ${ }^{-}$ intercalation compound corresponds to a single-phase compound with no evidence of crystallized impurities, for example, sodium nitrate, zinc oxide, or sodium ferulate salt. The new phase has a layer distance close to two times the nitrate phase. Consequently, both phases will have eclipsed basal peaks and both phases cannot be excluded from a mixture.

The 003 spacing value was $1.72 \mathrm{~nm}$, close to the value reported in the literature for LDH-ferulic obtained by coprecipitation $(1.69 \mathrm{~nm}) .^{30}$ With a brucite layer thickness of $0.48 \mathrm{~nm},{ }^{42}$ the gallery height of the interlayer region of

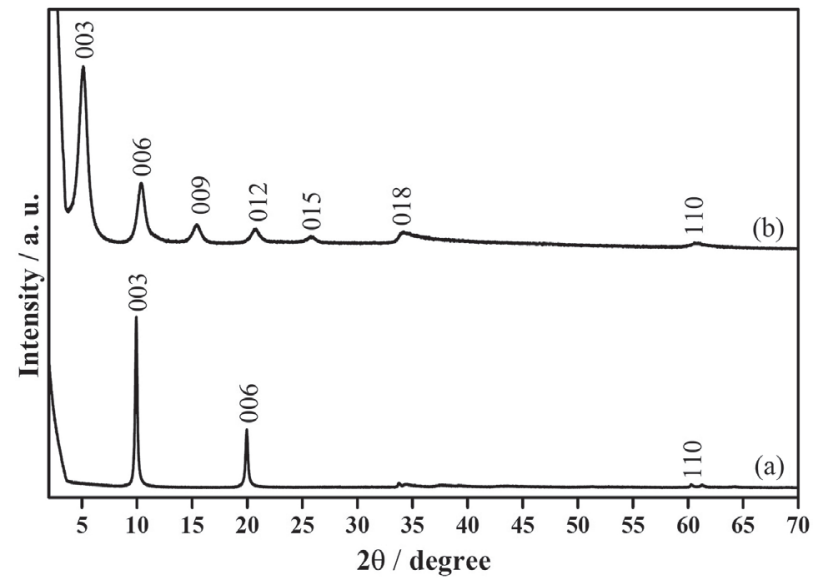

Figure 1. X-ray diffraction patters of the (a) pristine $\mathrm{LDH}\left(\mathrm{Zn} / \mathrm{Al}^{-} \mathrm{NO}_{3}^{-}\right)$ and (b) LDH-FER- intercalation compound.

the LDH-FER ${ }^{-}$intercalation compound can be estimated at about $1.24 \mathrm{~nm}$, within the range previously reported for FA intercalated into $\left[\mathrm{Zn} / \mathrm{Al}-\mathrm{NO}_{3}\right]-\mathrm{LDH} .{ }^{30,32}$ This gallery height suggests that ferulate anions may be arranged in the interlayer region in a zig-zag pattern with alternating phenol-acrylate $\pi-\pi$ interactions (see Scheme 1 ), as suggested in the literature. ${ }^{29,40}$ It is also worth noting that the 110 reflection appears at the same position for both the pristine LDH and LDH-FER ${ }^{-}$intercalation compound, indicating that the structure of the brucite layer is barely affected by the intercalation of the ferulate anions. Moreover, the crystalline domains in the organic phase are smaller than in the nitrate phase due to the basal lines broadening.

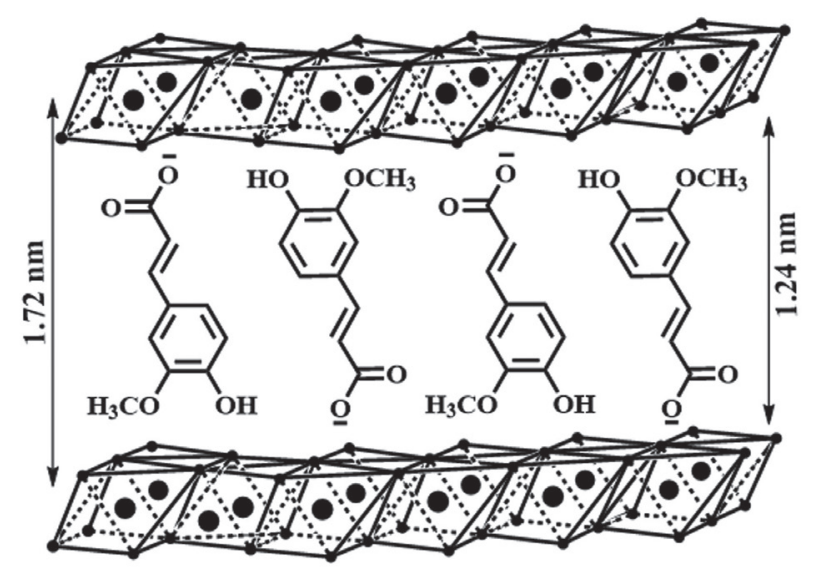

Scheme 1. Schematic model for the arrangement of FER- in LDH lattice.

Thermogravimetric and UV-Vis spectroscopy analyses

Weight loss as a function of temperature for ferulic acid (protonated neutral, FERH), pristine $\mathrm{LDH}\left(\mathrm{Zn} / \mathrm{Al}-\mathrm{NO}_{3}^{-}\right)$, and LDH-FER- ${ }^{-}$intercalation compound were obtained 
using DTA-TGA curves (Figure 2). FERH exhibits a singlestage thermal degradation, with an endothermic peak at $176.2^{\circ} \mathrm{C}$ followed by a complete thermal decomposition at temperatures above $300{ }^{\circ} \mathrm{C}$ due to the exothermic effect of decomposition phenomena in its DTA curve (Figure S1, Supplementary Information section). ${ }^{43}$ For pristine LDH, the thermal decomposition took place in two stages. ${ }^{44}$ The first weight loss was observed below $200{ }^{\circ} \mathrm{C}$, because of the loss of physically adsorbed and partial interlayer water, with an endothermic peak at $76^{\circ} \mathrm{C}$. The second weight loss took place in temperatures between 200 and $600{ }^{\circ} \mathrm{C}$ and can be attributed to the decomposition of the brucite-like layer and the removal of interlayer anions, with evolution of $\mathrm{NO}_{2}$ and $\mathrm{NO}$ gases from $\mathrm{LDH}\left(\mathrm{Zn} / \mathrm{Al}-\mathrm{NO}_{3}^{-}\right)$around 438 and $489^{\circ} \mathrm{C}$ in two stages (Figure S2, Supplementary Information section). However, a different pattern was observed in the LDH-FER ${ }^{-}$intercalation compound thermogravimetric curve, where the disappearance of the FERH molecules melting peak denoted a full intercalation of the compound into the matrix (Figure 2). The weight loss between 100 to $1000{ }^{\circ} \mathrm{C}$ is attributable to an intercalated FER ${ }^{-}$decomposition, ${ }^{29}$ with nitrate anions $\left(\mathrm{NO}_{3}^{-}\right)$, water $\left(\mathrm{H}_{2} \mathrm{O}\right)$ loss, and dehydroxylation of the inorganic layers. The thermally transformed products at $800^{\circ} \mathrm{C}$ could be $\mathrm{ZnO}$ and $\mathrm{ZnAl}_{2} \mathrm{O}_{4}$, as described in the literature. ${ }^{44}$

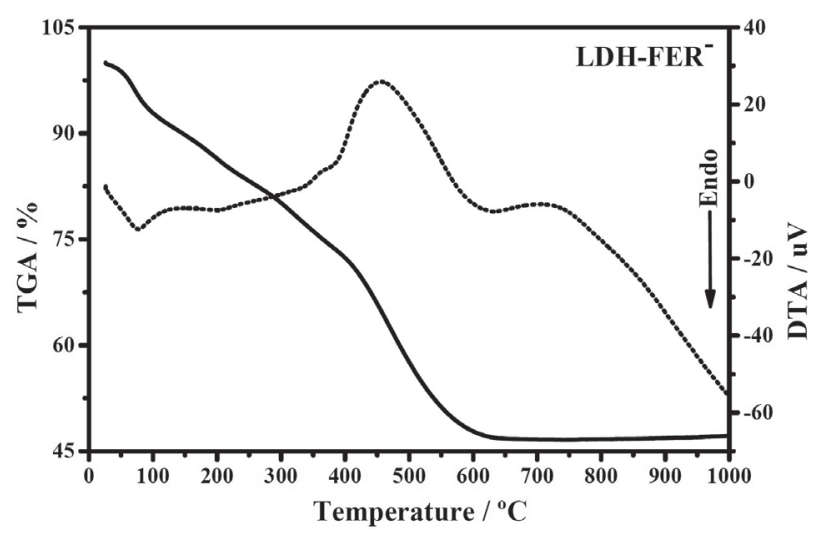

Figure 2. DTA-TGA curves of the LDH-FER- intercalation compound. Solid line: TGA; dotted line: DTA.

From the TGA analyses and the cationic ratio ( $\mathrm{Zn} / \mathrm{Al})$ obtained from ICP, the composition of the positive charge of the brucite layer was calculated, where the amount of intercalated $\mathrm{FER}^{-}$and water of hydration per formula unit were obtained (Table 1). These results are consistent with those found in the literature. ${ }^{32}$ Furthermore, Figure 3 shows the UV-Vis spectra of both pure FERH and FER ${ }^{-}$ release from the LDH-FER ${ }^{-}$complex. These data were obtained using a phosphate buffer solution at $\mathrm{pH} 7.40$ and also in the solid state, as described above in the "Sample characterization" sub-section. In solution, the absorbance peaks at 216 and $290 \mathrm{~nm}$ of the methoxyphenol part and $314 \mathrm{~nm}$ of the acrylate part, representing the $\mathrm{n} \rightarrow \pi^{*}$ and $\pi \rightarrow \pi^{*}$ transition, respectively, ${ }^{40}$ show that intercalation compound was capable to deliver ferulate anion making it suitable for interaction with its biological targets. In addition, the UV-Vis solid state spectrum showed peaks at 383 and $387 \mathrm{~nm}$ of the energy transitions of the $\pi-\pi$ to $\pi \rightarrow \pi^{*}$ interactions, which correspond to FERH alone and to the ferulate anion into LDH layers, respectively. It is also important to note that the amount of FER ${ }^{-}$intercalated into LDH gallery was calculated at $42.6 \pm 0.8 \%\left(\mathrm{~m} \mathrm{~m}^{-1}\right)$ using UV-Vis spectroscopy analysis, which is in accordance with the range previously reported for ferulate anion intercalated into $\mathrm{Mg} / \mathrm{Al}-\mathrm{NO}_{3} \mathrm{LDH}$ by anion exchanger (34-48\%). ${ }^{40,45}$

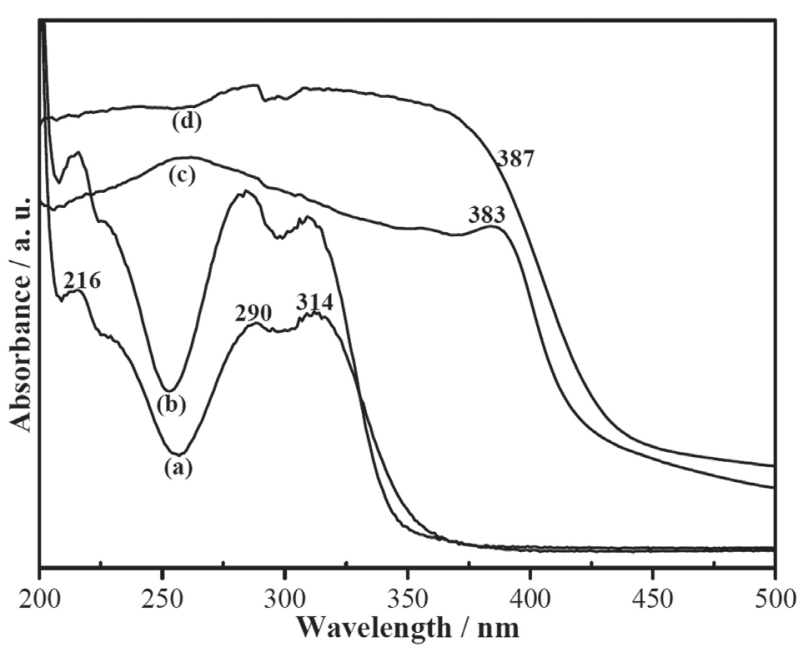

Figure 3. Solution UV-Vis spectra of (a) FERH, (b) released FER ${ }^{-}$from the LDH-FER ${ }^{-}$, and (c) solid-state UV-Vis spectra of the neutral FERH and (d) LDH-FER- intercalation compound.

Table 1. XRD structural and microstructural information obtained for the LDH and LDH-FER- intercalation compound

\begin{tabular}{|c|c|c|c|c|c|}
\hline \multirow{2}{*}{ Sample } & \multirow{2}{*}{ Average chemical composition } & \multirow{2}{*}{$\begin{array}{c}\text { Total weight } \\
\operatorname{loss}^{\mathrm{a}} / \%\end{array}$} & \multirow{2}{*}{$\begin{array}{l}\text { Weight of } \\
\text { FER }^{-b} / \%\end{array}$} & \multicolumn{2}{|c|}{ Cell parameter } \\
\hline & & & & $a / \mathrm{nm}$ & $c / \mathrm{nm}$ \\
\hline $\mathrm{LDH}\left(\mathrm{Zn} / \mathrm{Al}-\mathrm{NO}_{3}^{-}\right)$ & {$\left[\mathrm{Zn}_{0.68} \mathrm{Al}_{0.32}(\mathrm{OH})_{2}\right]^{0.32+}\left[\left(\mathrm{NO}_{3}\right)_{0.32}, 0.54 \mathrm{H}_{2} \mathrm{O}\right]^{0.32-}$} & 38.5 & 0.0 & 0.306 & 2.67 \\
\hline LDH-FER $^{-}$ & {$\left[\mathrm{Zn}_{0.68} \mathrm{Al}_{0.32}(\mathrm{OH})_{2}\right]^{0.32+}\left[\left(\mathrm{NO}_{3}\right)_{0.03} \mathrm{FER}_{0.29}^{-}, 0.52 \mathrm{H}_{2} \mathrm{O}\right]^{0.32-}$} & 53.1 & 42.6 & 0.305 & 4.84 \\
\hline
\end{tabular}

${ }^{\mathrm{a} B a s e d}$ on TG analyses; ${ }^{\text {bbased on UV-Vis titration. FER }}{ }^{-}$ferulate anion; $a$ and $c$ : lattice constants; $\mathrm{LDH}\left(\mathrm{Zn} / \mathrm{Al}-\mathrm{NO}_{3}\right)$ : $\mathrm{Zn} / \mathrm{Al}$ layered double hydroxide; LDH-FER $^{-}$: ferulate anion intercalated into a layered double hydroxide. 
Infrared and FT-Raman analysis

Infrared spectroscopy was used to analyze the vibrational behavior of FERH before and after their intercalation into the $\mathrm{LDH}\left(\mathrm{Zn} / \mathrm{Al}-\mathrm{NO}_{3}{ }^{-}\right)$galleries. Figure 4 shows these results, which are in agreement with the data reported in the literature for these types of materials. ${ }^{31,32,40}$

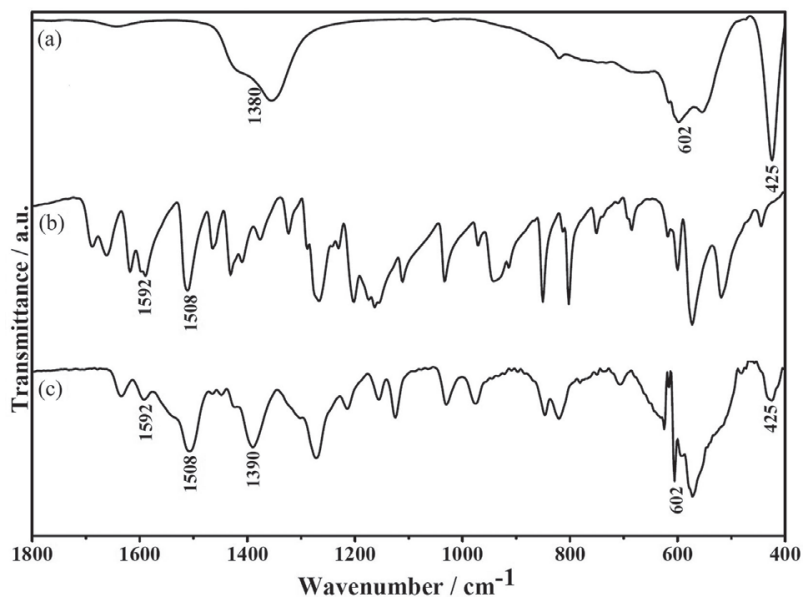

Figure 4. FTIR spectra of (a) pristine $\mathrm{LDH}\left(\mathrm{Zn} / \mathrm{Al}-\mathrm{NO}_{3}^{-}{ }^{-}\right)$, (b) pure FERH, and (c) LDH-FER ${ }^{-}$intercalation compound.

The presence of nitrate anions $\left(\mathrm{NO}_{3}^{-}\right)$is identified by a characteristic peak at $1380 \mathrm{~cm}^{-1}$, unambiguously assigned to its $v_{3}$ vibrational mode. ${ }^{46}$ The disappearance of the $\mathrm{NO}_{3}{ }^{-}$anion band is a result of the anionic exchange of the coprecipitation method. New vibrational modes for $\mathrm{FER}^{-}$(Figure 4) correspond to those previously proposed. ${ }^{47}$ For example, the very strong band observed in the FTIR spectrum at $1508 \mathrm{~cm}^{-1}$ corresponds to $\mathrm{C}-\mathrm{C}$ stretching vibration for both aromatic and propanoic acids. Moreover, the appearance of antisymmetric $v_{\text {antisym }}\left(\mathrm{COO}^{-}\right)$ and symmetric $v_{\text {sym }}\left(\mathrm{COO}^{-}\right)$stretching modes of carboxylate groups observed at 1592 and $1390 \mathrm{~cm}^{-1}$, respectively, indicates that a $\mathrm{FER}^{-}$has been intercalated, as previously reported in the literature for $\mathrm{ZnAl-FA}{ }^{32}$ The difference between $v_{\text {antisym }}\left(\mathrm{COO}^{-}\right)$and $v_{\text {sym }}\left(\mathrm{COO}^{-}\right)$stretching was ca. $202 \mathrm{~cm}^{-1}$. This clearly indicates the deprotonated nature of the intercalated $\mathrm{FER}^{-}$compared to FERH. In addition, the broad absorption band at $3450 \mathrm{~cm}^{-1}$ corresponds to the stretching frequency mode of $\mathrm{O}-\mathrm{H}$ groups in the brucitelike layer and interlayer water. Similarly, absorption at $1645 \mathrm{~cm}^{-1}$ originates from the $\mathrm{O}-\mathrm{H}$ bending vibration of hydroxyl groups. ${ }^{46}$ Bands at 425 and $602 \mathrm{~cm}^{-1}$ correspond to the lattice vibration modes attributed to $\mathrm{Al}-\mathrm{OH}$ and $\mathrm{Zn}-\mathrm{OH}$ vibrations. ${ }^{32,48}$ Therefore, our results suggest that $\mathrm{FER}^{-}$was stabilized between stacked LDH layers, most likely as a result of an electrostatic interaction, as previously proposed by Kang et al. ${ }^{40}$
Raman spectroscopy analysis was also used to complement the infrared study. The data obtained are shown in Figure S3 (Supplementary Information section) for free FERH, pristine $\mathrm{LDH}\left(\mathrm{Zn} / \mathrm{Al}-\mathrm{NO}_{3}{ }^{-}\right)$, and LDH-FER ${ }^{-}$intercalation compound. In the LDH sample, a band related to the nitrate (symmetry $\mathrm{D}_{3 \mathrm{~h}}$ ) can be observed at $1055 \mathrm{~cm}^{-1}$, as reported by Kloprogge et al. ${ }^{48}$ The measured FERH spectrum confirms that the drug is pure and corresponds well with the full indexation proposed in the literature. ${ }^{47,49}$ The FT-Raman analysis confirms the intercalation of $\mathrm{FER}^{-}$in the hosts as evidenced by ring breathing at $673,814,1177 \mathrm{~cm}^{-1}$ and $\delta \mathrm{ip}(=\mathrm{C}-\mathrm{H})$ at 1240 and $1273 \mathrm{~cm}^{-1}$, and by the asymmetric and symmetric vibrations of $\delta\left(\mathrm{CH}_{3}\right)$ and aromatic $\mathrm{C}=\mathrm{C}$ stretching at 1601 and $1630 \mathrm{~cm}^{-1}$. Moreover, two bands at 573 and $710 \mathrm{~cm}^{-1}$ are attributed to $\mathrm{M}-\mathrm{OH}$ of the $\mathrm{LDH}_{-} \mathrm{FER}^{-}$intercalation compound.

\section{SEM}

The scanning electron micrographs of the samples are shown in Figure 5 for both pristine LDH (Figure 5a) and the LDH-FER $^{-}$intercalation compound (Figure 5b). The image suggests an aggregated sheet-like morphology, characteristic of hydrotalcite materials, ${ }^{33,50}$ with a diameter smaller than $1 \mu \mathrm{m}$. This indicates that the particles are composed of a small number of layers, which is consistent with intercalated ferulate anion at room temperature. Moreover, the size of the particle is consistent with this material type as shown in previous studies..$^{29,32}$
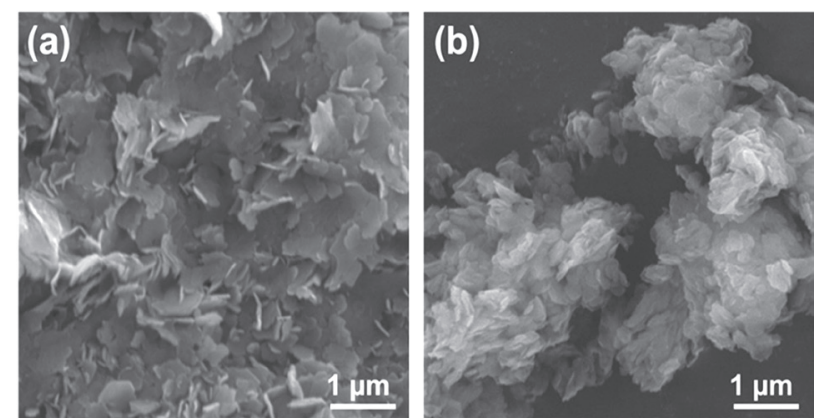

Figure 5. Scanning electron micrographs of (a) pristine LDH and (b) the LDH-FER- intercalation compound.

\section{Release study of LDH-FER ${ }^{-}$}

Figure 6 shows the release profiles of $\mathrm{FER}^{-}$from its $\mathrm{LDH}_{-} \mathrm{FER}^{-}$intercalation compound at different $\mathrm{pH}$ values, indicating that the release rate of ferulate anion from the LDH-FER ${ }^{-}$is $\mathrm{pH}$-dependent. The release rate at $\mathrm{pH} 7.4$ is remarkably lower than that at $\mathrm{pH}$ 5.0. It is noteworthy that in this $\mathrm{pH}$ range there is predominance of the ionic form of 
the ferulic acid. ${ }^{51}$ The percentage release of ferulate anion from $\mathrm{LDH}_{-\mathrm{FER}^{-}}$is of approximately 90 and $71 \%$ after $10 \mathrm{~h}$ when exposed to $\mathrm{pH} 5.0$ and 7.4, respectively. The release of ferulate anion from the LDH-FER- intercalation compound follows different molecular mechanisms at $\mathrm{pH} 5.0$ and 7.4. ${ }^{32,52}$ Tyner et al..$^{53}$ found that $\mathrm{Zn} / \mathrm{Al}-\mathrm{LDH}$ is more stable at $\mathrm{pH} 7.4$ than 4.8 due to electrostatic interactions between the sodium cholate anions and the positively charged Zn/Al-LDH layers. ${ }^{53}$ Moreover, they suggested that the release of sodium cholate at $\mathrm{pH} 7.4$ occurs via an ion exchange with the ions in the buffer solution, while the release at $\mathrm{pH} 4.8$ occurs through both dissolution of the LDH layers and ion exchange. ${ }^{53,54}$ This lower release rate of ferulate anion from the intercalation compound at pH 7.4 suggests that the LDH-FER ${ }^{-}$could be a potential drug delivery system. According to the literature, ${ }^{32}$ the burst effect observed in the matrix during the first $2 \mathrm{~h}$, followed by a slow release from the second to the tenth hour, could be due to the release of intercalated ions. The second slow-release stage can be attributed to the release of ferulate anion from deeper interlayer sites, where the effective distance to diffuse up to the edges reduces the release rate, together with a possible increase in the rigidity of the layers. ${ }^{32}$

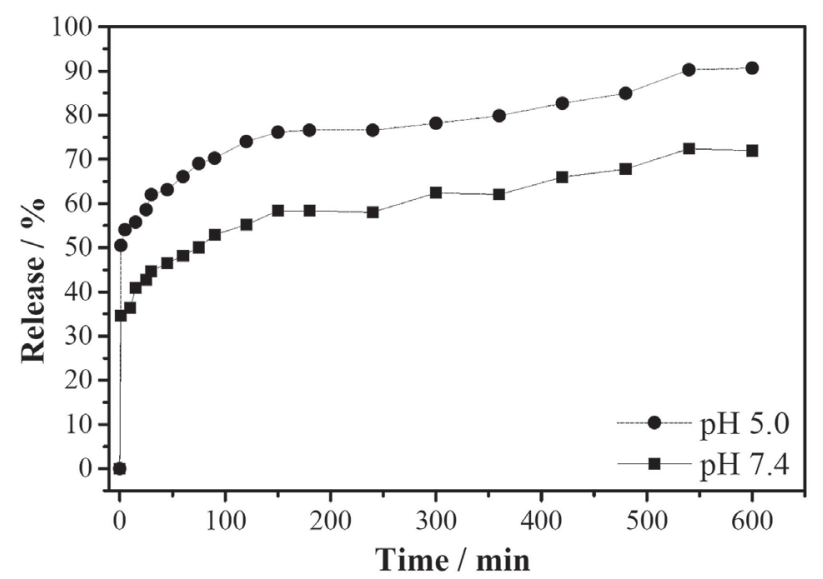

Figure 6. Release profiles for ferulate anion from the LDH-FERintercalation compound at $\mathrm{pH} 7.4$ and 5.0.

Effect of layered double hydroxide (LDH-FER ${ }^{-}$) on promastigotes and intracellular amastigotes of Leishmania (L.) amazonensis

The antipromastigote activity assay (Figure 7a) showed that $\mathrm{LDH}^{-\mathrm{FER}^{-}}$promoted a decrease of approximately $10 \%$ (0.4 and $\left.0.9 \mu \mathrm{g} \mathrm{mL}^{-1}\right), 18 \%\left(2.1 \mu \mathrm{g} \mathrm{mL}^{-1}\right), 20 \%\left(4.3 \mu \mathrm{g} \mathrm{mL}^{-1}\right)$, and $30 \%\left(8.5 \mu \mathrm{g} \mathrm{mL}^{-1}\right)$ of $L$. (L.) amazonensis promastigotes $\left(\mathrm{IC}_{50}=16.6 \mu \mathrm{g} \mathrm{mL}^{-1}\right) . \mathrm{LDH} \mathrm{FER}^{-}$demonstrated partially ineffective action against the promastigote forms of L. (L.) amazonensis. However, the leishmanicidal activity of a compound is not evaluated only by its action on the extracellular promastigote forms. It is important to also consider the action of the compound against the intracellular amastigote forms found in the lesions of patients with leishmaniasis. Then, the activity of LDH$\mathrm{FER}^{-}$against intracellular amastigote form was evaluated following the experimental procedure described in "Antiamastigote assay" sub-section. After the biological

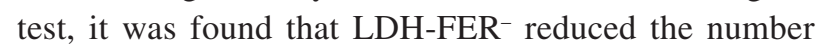
of L. (L.) amazonensis amastigotes $\left(\mathrm{IC}_{50}=1.78 \mu \mathrm{g} \mathrm{mL} \mathrm{m}^{-1}\right)$ after $72 \mathrm{~h}$ of treatment (Figure $7 \mathrm{~b}$ ). Reductions of approximately $58 \%\left(0.9 \mu \mathrm{g} \mathrm{mL}^{-1}\right), 71 \%\left(2.1 \mu \mathrm{g} \mathrm{mL}^{-1}\right)$, and $86 \%\left(4.3 \mu \mathrm{g} \mathrm{mL}^{-1}\right)$ were observed. It is interesting to note that $\mathrm{LDH}^{-F} \mathrm{R}^{-}$at a concentration of $4.3 \mu \mathrm{g} \mathrm{mL^{-1 }}$ presented an amastigotes reduction rate close to that observed in cells treated with AMP-B (see Figure 7). It is important to clarify that $\mathrm{IC}_{50}, \mathrm{CC}_{50}$, survival index and $\%$ of viable cells were calculated considering the amount of ferulate anion present in LDH-FER ${ }^{-}$used for antipromastigote and antiamastigote activity assay.

The literature reports that ferulic acid (FERH) isolated from Pluchea carolinensis presents leishmanicidal action against L. (L.) amazonensis. ${ }^{16}$ One study showed that FERH promoted a reduction in the number of promastigotes in Leishmania tropica after 3 days of cultivation. ${ }^{15}$ Another experimental work suggests that ferulic acid presented no inhibition of amastigote forms from L. (L.) amazonensis inside $\mathrm{J} 774$ macrophages. ${ }^{55}$ The present study shows for the first time that $\mathrm{FER}^{-}$intercalated into pristine $\mathrm{LDH}\left(\mathrm{Zn} / \mathrm{Al}-\mathrm{NO}_{3}^{-}\right)$has leishmanicidal action. Our results show that the $\mathrm{LDH}^{-\mathrm{FER}^{-}}$intercalation compound presented a more effective association against amastigote forms of $L$. (L.) amazonensis than against promastigotes. Leishmania amastigotes are obligate intracellular forms that can be found in the parasitophorous vacuoles of phagocytic cells, where the $\mathrm{pH}$ is acidic and where there are numerous lysosomal enzymes. ${ }^{2}$ LDH nanoparticles are negatively charged which facilitates their interaction with cell membranes, favoring the process of endocytosis. ${ }^{56} \mathrm{It}$ is interesting to note that in the presence of an acidic $\mathrm{pH}$, LDH nanoparticles dissolve and release their contents. ${ }^{57}$ Thus, the action of the LDH-FER- intercalation compound against amastigote forms seems to occur by the degradation of the LDH-FER ${ }^{-}$in an acidic environment, causing the release of all intercalated $\mathrm{FER}^{-}$eventually prompting the parasite to die. Obviously, this proposition awaits further experimental studies.

In relation to the cytotoxicity assay, no reduction in macrophages viability was observed after treatment with different concentrations of FER ${ }^{-}$released from $\mathrm{LDH}^{-\mathrm{FER}^{-}}$ (0.9-17 $\mu \mathrm{g} \mathrm{mL}^{-1}$ ) with a $\mathrm{CC}_{50}$ of $212.61 \mu \mathrm{g} \mathrm{mL} \mathrm{m}^{-1}$ (Figure 8). 

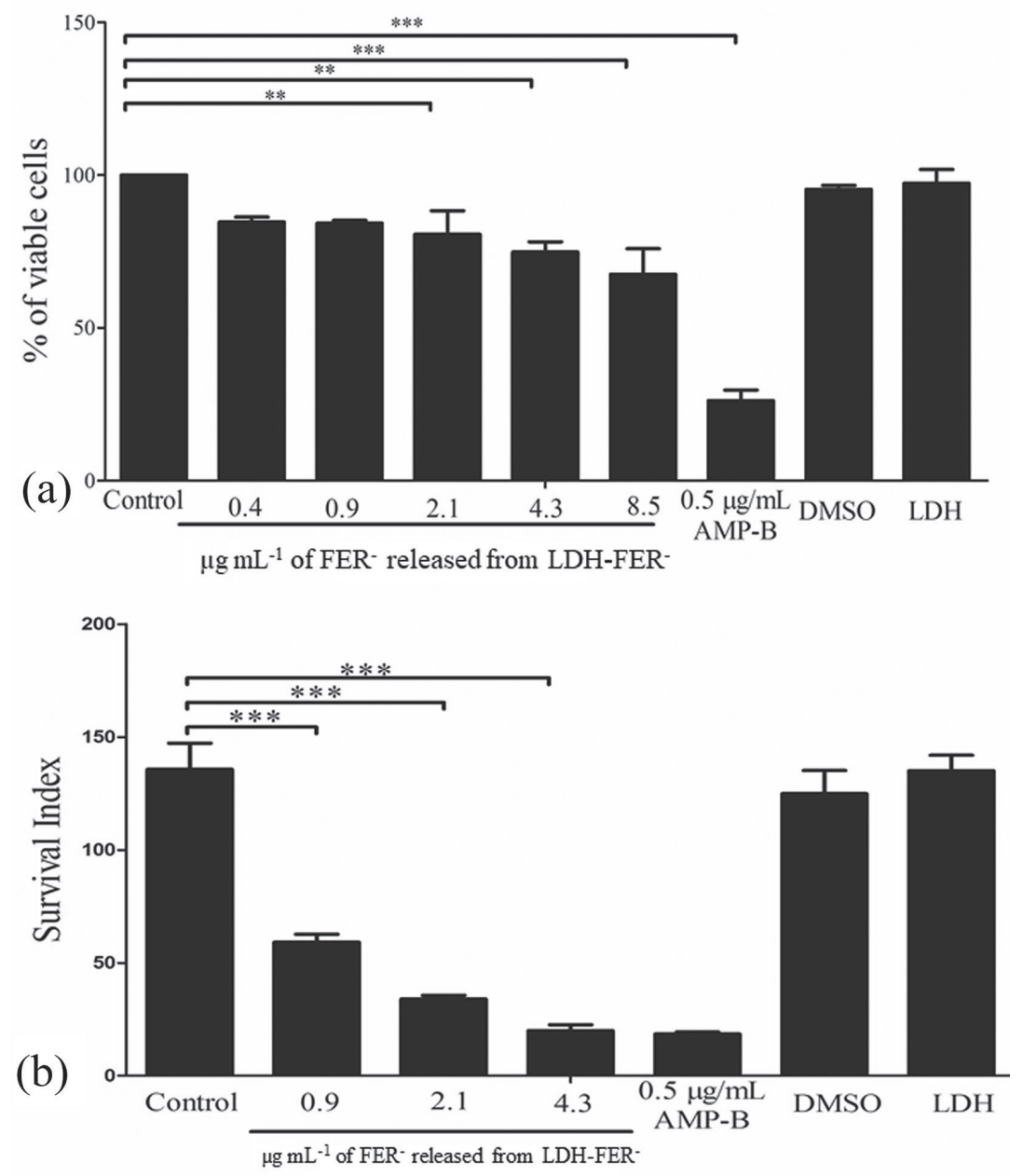

Figure 7. Leishmanicidal action of ferulate anion released from LDH-FER ${ }^{-}$. (a) Antipromastigote activity in vitro. The promastigotes of $L$. ( $L$.) amazonensis were treated with different concentrations of LDH-FER- $\left(0.4-8.5 \mu \mathrm{g} \mathrm{mL}^{-1}\right)$ for $96 \mathrm{~h}$. For the negative control, Leishmania promastigotes were incubated with DMSO and LDH (Zn/Al- $\left.\mathrm{NO}_{3}\right)$. (b) Antiamastigote activity. Macrophages J774-G8 infected with L. (L.) amazonensis were treated with LDH-FER- $(0.9-$ $4.3 \mu \mathrm{g} \mathrm{mL}{ }^{-1}$ ) for $72 \mathrm{~h}$. AMP-B at a concentration of $0.5 \mu \mathrm{g} \mathrm{mL}-1$ was used as a positive control for both (a) and (b) tests. Analysis of variance (ANOVA), followed by Tukey's test: ** $p<0.05 ; * * * p<0.001$.

It is important to keep in mind that the comparison of different experiment with distinct protocols could lead to wrong interpretations. However, it is interesting to compare the biological activity of our LDH-FER ${ }^{-}$intercalation compound with the experimental data of other compounds from literature. In this work was started the comparison with miltefosine and AMP-B that are important drugs for the treatment of leishmaniasis ${ }^{6}$ and are more effective than FERH. ${ }^{58}$ The in vitro cytotoxicity study of amphotericin B and miltefosine presented $\mathrm{CC}_{50}$ of 57.3 and $34.4 \mu \mathrm{g} \mathrm{mL}^{-1}$, respectively. ${ }^{58}$ In addition, the SI observed for both drugs correspond to 38.2 and 5.8 , respectively, ${ }^{58}$ which is lower than the SI of FER ${ }^{-}$released from LDH-FER ${ }^{-}$(see Table 2). It is also worth mentioning that the inhibitory effect of the LDH-FER- intercalation compound is slightly lower than ferulic acid (FERH) but it is important to emphasize that the SI of the FER ${ }^{-}$released from LDH-FER ${ }^{-}$corresponds to 119.4, while the SI of FERH is 17 (Table 2). Therefore,
LDH-FER $^{-}$may be used as potential drug with low risk of toxicity.

The present study demonstrated that LDH-FER ${ }^{-}$ presents selective action against $L$. $(L$.) amazonensis. LDH-FER ${ }^{-}$eliminated amastigote forms of Leishmania without causing damage to the host cell. Substances intercalated with LDH have advantages compared to non-intercalated substances. LDH has a low toxicity and a controlled release of the intercalated compounds which makes its use attractive in the treatment of various diseases. ${ }^{59}$ Indeed, the LDH-FER- intercalation compound was selective against $L$. (L.) amazonensis, presenting an SI of 119.4 for intracellular amastigote. Based on these results, LDH-FER ${ }^{-}$was shown to act against $L$. (L.) amazonensis amastigotes with no negative effect on mammalian cells, suggesting that the intercalation compound could be used as start point for the development of a new leishmanicidal agent. 


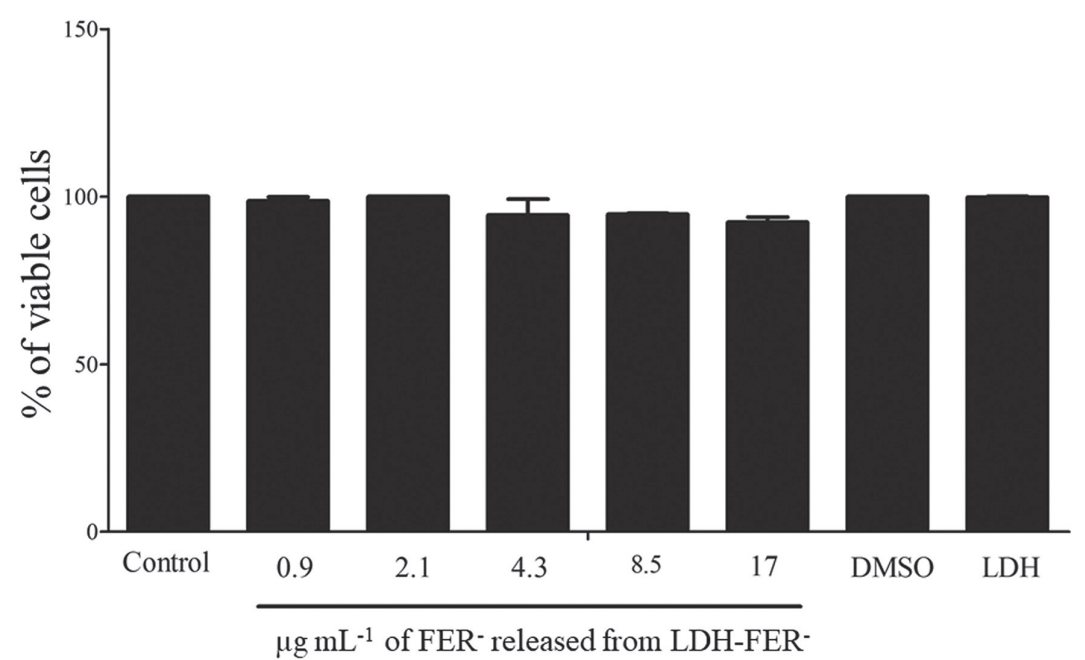

Figure 8. Effect of FER- released from LDH-FER ${ }^{-}$on the mouse macrophage cell line J774 viability assay by the MTT method. J774-G8 macrophages were treated with different concentrations of LDH-FER ${ }^{-}(0.9-17 \mu \mathrm{g} \mathrm{mL}-1)$ for $72 \mathrm{~h}$. As a negative control, J774 macrophages were incubated with DMSO and $\mathrm{LDH}\left(\mathrm{Zn} / \mathrm{Al}-\mathrm{NO}_{3}\right)$.

Table 2. Antileishmanial and cytotoxic activities for the FER- released from LDH-FER- intercalation compound

\begin{tabular}{lcccc}
\hline \multirow{2}{*}{ Sample } & Promastigote & Amastigote & Macrophage & \multirow{2}{*}{ Selectivity index } \\
\cline { 2 - 4 } & $\left.\mathrm{IC}_{50}{ }^{\mathrm{a}} \pm \mathrm{SD}^{\mathrm{b}} /(\mu \mathrm{g} \mathrm{mL})^{-1}\right)$ & $\mathrm{IC}_{50} \pm \mathrm{SD} /\left(\mu \mathrm{g} \mathrm{mL}^{-1}\right)$ & $\mathrm{CC}_{50}{ }^{c} \pm \mathrm{SD} /\left(\mu \mathrm{g} \mathrm{mL}{ }^{-1}\right)$ & 119.4 \\
\hline FER $^{-}$released from LDH-FER & 16.6 & 1.78 & 212.61 & 1 \\
FERH $^{16}$ & $0.3 \pm 0.1$ & $1.5 \pm 0.1$ & $25.1 \pm 0.5$ & 17 \\
\hline
\end{tabular}

${ }^{\mathrm{a}} \mathrm{IC}_{50}: 50 \%$ inhibitory concentration (concentration that causes $50 \%$ of growth inhibition); ${ }^{\mathrm{b}} \mathrm{SD}$ : standard deviation; ${ }^{\mathrm{c}} \mathrm{CC}_{50}:$ medium cytotoxic concentration (concentration that causes $50 \%$ of mortality). Selectivity index $=\mathrm{CC}_{50}$ for macrophages $/ \mathrm{IC}_{50}$ for intracellular amastigotes $\left(\mu \mathrm{g} \mathrm{mL} \mathrm{m}^{-1}\right.$ ). $\mathrm{FER}^{-}$: ferulate anion;

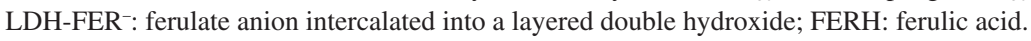

\section{Conclusions}

In this work, ferulate anion was intercalated into a LDH by a simple coprecipitation method. The anion incorporated within the LDH interlayer space (LDH-FER-) was analyzed by XRD, FTIR, Raman, DTA-TGA, and UV-Vis spectroscopy. The analysis of the intercalated compound showed an intercalation percentage of $42.6 \%$ and an increase of the interlayer space from nitrate anion due to the presence of the ferulate anions. Moreover, it was also demonstrated that the LDH-FER ${ }^{-}$could be used as an efficient leishmanicidal intercalation compound against amastigote forms of Leishmania (Leishmania) amazonensis. The release of FER- from LDH-FER ${ }^{-}$is of ca. $90 \%$ at $\mathrm{pH} 5$ after $10 \mathrm{~h}$, which is $20 \%$ more than the ferulate anion released at $\mathrm{pH}$ 7.4. This study demonstrates, for the first time, the action of LDH-FER ${ }^{-}$on $L$. (L.) amazonensis in vitro.

Our results also highlight the importance of $\mathrm{LDH}$ as a potential drug delivery vehicle for potential treatment of cutaneous leishmaniasis without any side effect. Overall, LDH-FER ${ }^{-}$could be useful for the selective treatment of cutaneous leishmaniasis and may be of great potential as an anti-leishmanial agent.

\section{Supplementary Information}

Supplementary data (DTA-TGA curves for neutral FERH and pristine LDH $\left(\mathrm{Zn} / \mathrm{Al}-\mathrm{NO}_{3}\right)$ samples, and FT-Raman spectra of pristine LDH $\left(\mathrm{Zn} / \mathrm{Al}-\mathrm{NO}_{3}\right)$, neutral FERH, and LDH-FER ${ }^{-}$intercalation compound) are available free of charge at http://jbcs.sbq.org.br as PDF file.

\section{Acknowledgments}

This work was supported by the Conselho Nacional de Desenvolvimento Científico e tecnológico (CNPq) (grant 441922/2014 and 424820/2016), PROPESP-UFPA, the Instituto Nacional de Biologia Estrutural e BioimagemINBEB (CNPq-grant number 465395/2014), and also Coordenação de Aperfeiçoamento de Pessoal de Nível Superior (CAPES) through the Programa Nacional de Pós Doutorado (PNPD No. 01/2017) of the Programa de Pós-Graduação em Química-PPGQ/UFPA. We also gratefully acknowledge the use of the facilities at LABNANO-AMAZON/UFPA. 


\section{References}

1. Kedzierski, L.; Hum. Vaccines 2011, 7, 1204.

2. Von Stebut, E.; J. Dtsch. Dermatol. Ges. 2015, 13, 191.

3. Carvalho, A. K.; Silveira, F. T.; Passero, L. F.; Gomes, C. M.; Corbett, C. E.; Laurenti, M. D.; Parasite Immunol. 2012, 34, 395.

4. Soong, L.; Henard, C. A.; Melby, P. C.; Semin. Immunopathol. 2012, 34, 735 .

5. Kling, J. C.; Körner, H.; Int. J. Parasitol. 2013, 43, 417.

6. Barrett, M. P.; Croft, S. L.; Br. Med. Bull. 2012, 104, 175.

7. Rodrigues, A. P. D.; Farias, L. H. S.; Carvalho, A. S. C.; Santos, A. S.; Nascimento, J. L. M.; Silva, E. O.; PLoS One 2014, 9, 1.

8. Brenzan, M. A.; Nakamura, C. V.; Prado Dias Filho, B.; UedaNakamura, T.; Young, M. C. M.; Aparício Garcia Cortez, D.; Parasitol. Res. 2007, 101, 715.

9. Monzote, L.; García, W. H. P. M.; Piñón, A.; Setzer, W. N.; Rec. Nat. Prod. 2016, 10, 269.

10. Bafghi, A. F.; Bagheri, S. M. M.; Hejazian, S. H.; J. Appl. Environ. Biol. Sci. 2014, 4, 113.

11. Monzote, L.; García, M.; Montalvo, A. M.; Scull, R.; Miranda, M.; Mem. Inst. Oswaldo Cruz 2010, 105, 168.

12. Al-Sokari, S. S.; Ali, N. A. A.; Monzote, L.; Al-Fatimi, M. A.; BioMed Res. Int. 2015, 2015, 938747.

13. Takahashi, M.; Fuchino, H.; Sekita, S.; Satake, M.; Phytother. Res. 2004, 18, 573.

14. Silva, B. J. M. D.; Silva, R. R. P. D.; Rodrigues, A. P. D.; Farias, L. H. S.; Nascimento, J. L. M.; Silva, E. O.; Micron 2016, 82, 25.

15. Mohammad, B. I.; Shammary, M. N. A.; Mageed, R. H. A.; Yousif, N. G.; J. Parasit. Dis. 2015, 39, 663.

16. Montrieux, E.; Perera, W. H.; García, M.; Maes, L.; Cos, P.; Monzote, L.; Parasitol. Res. 2014, 113, 2925.

17. Kikugawa, M.; Tsuchiyama, M.; Kai, K.; Sakamoto, T.; Appl. Microbiol. Biotechnol. 2012, 95, 615.

18. Crepaldi, E. L.; Pavan, P. C.; Valim, J. B.; J. Braz. Chem. Soc. 2000, 11, 64.

19. Nakagaki, S.; Castro, K. A. D. F.; Ucoski, G. M.; Halma, M.; Prévot, V.; Forano, C.; Wypych, F.; J. Braz. Chem. Soc. 2014, 25, 2329.

20. Marcato, P. D.; Parizotto, N. V.; Martinez, D. S. T.; Paula, A. J.; Ferreira, I. R.; Melo, P. S.; Durán, N.; Alves, O. L.; J. Braz. Chem. Soc. 2013, 24, 266.

21. Barahuie, F.; Hussein, M. Z.; Fakurazi, S.; Zainal, Z.; Int. J. Mol. Sci. 2014, 15, 7750 .

22. Choi, S. J.; Oh, J. M.; Choy, J. H.; J. Nanosci. Nanotechnol. 2008, 8, 5297.

23. Abdolmohammad-Zadeh, H.; Layered Double Hydroxides: Application to Sample Preparation Methods; LAP Lambert Academic Publishing: Bergisch Gladbach, 2013.

24. Capsoni, D.; Quinzeni, I.; Bruni, G.; Friuli, V.; Maggi, L.; Bini, M.; J. Pharm. Sci. 2018, 107, 267.
25. Zhang, K.; Xu, Z. P.; Lu, J.; Tang, Z. Y.; Zhao, H. J.; Good, D. A.; Wei, M. Q.; Int. J. Mol. Sci. 2014, 15, 7409.

26. Cunha, V. R.; Guilherme, V. A.; Paula, E.; Araujo, D. R.; Silva, R. O.; Medeiros, J. V.; Leite, J. R.; Petersen, P. A.; Foldvari, M.; Petrilli, H. M.; Constantino, V. R.; Mater. Sci. Eng., C 2016, 58,629 .

27. Williams, G. R.; O'Hare, D.; J. Mater. Chem. 2006, 16, 3065.

28. Evans, D. G.; Duan, X.; Chem. Commun. 2006, 5, 485.

29. Rossi, C.; Schoubben, A.; Ricci, M.; Perioli, L.; Ambrogi, V.; Latterini, L.; Aloisi, G. G.; Rossi, A.; Int. J. Pharm. 2005, 295 , 47.

30. Coelho, C.; Hennous, M.; Verney, V.; Leroux, F.; RSC Adv. 2012, 2, 5430 .

31. Kim, H. J.; Ryu, K.; Kang, J. H.; Choi, A. J.; Kim, T. I.; Oh, J. M.; Reassembly 2013, 2013, 421967.

32. Lima, E.; Flores, J.; Cruz, A. S.; Leyva-Gómez, G.; Krötzsch, E.; Microporous Mesoporous Mater. 2013, 181, 1.

33. Sousa, R.; Jouin, J.; Masson, O.; Remondiere, F.; Lemarchand, A.; Colas, M.; Thomas, P.; Lameira, J.; Bastos, G. N. T. B.; Lima, A. B.; Nascimento, J. L. M.; Santos, M. A.; Monteiro, W. R.; Alves, C. N.; J. Am. Ceram. Soc. 2017, 100, 2712.

34. Masson, O.; Peakoc profile fitting program, version 1.0; Université de Limoges, France, 2010. Available at http://www. esrf.eu/Instrumentation/software/data-analysis/OurSoftware/ PEAKOC, accessed in January 2019.

35. Thompson, P.; Cox, D. E.; Hastings, J. B.; J. Appl. Crystallogr. 1987, 20, 79.

36. da Silva, R. R. P.; Silva, B. J. M.; Rodrigues, A. P. D.; Farias, L. H. S.; Silva, M. N.; Alves, D. T. V.; Bastos, G. N. T.; Nascimento, J. L. M.; Silva, E. O.; BMC Complementary Altern. Med. 2015, 15, 249.

37. SigmaPlot, version 12.0 for Windows; Systat Software Inc., San Jose, California, USA, 2011.

38. Rodrigues, A. P.; Carvalho, A. S.; Santos, A. S.; Alves, C. N.; Nascimento, J. L.; Silva, E. O.; Cell Biol. Int. 2011, 35, 335.

39. Lv, L.; Sun, P.; Gu, Z.; Du, H.; Pang, X.; Tao, X.; Xu, R.; Xu, L.; J. Hazard. Mater. 2009, 161, 1444.

40. Kang, H.; Kim, H. J.; Yang, J. H.; Kim, T. H.; Choi, G.; Paek, S. M. ; Choi, A. J.; Choy, J. H.; Oh, J. M.; Appl. Clay Sci. 2015, 113,32 .

41. Kim, H.-J.; Ryu, K.; Kang, J.-H.; Choi, A.-J.; Kim, T.-i.; Oh, J.-M.; Sci. World J. 2013, 2013, 421967.

42. Newman, S. P.; Jones, W.; New J. Chem. 1998, 22, 105.

43. Santos, N. A.; Cordeiro, A. M. T. M.; Damasceno, S. S.; Aguiar, R. T.; Rosenhaim, R.; Filho, J. R. C.; Santos, I. M. G.; Maia, A. S.; Souza, A. G.; Fuel 2012, 97, 638.

44. Velu, S.; Ramkumar, V.; Narayanan, A.; Swamy, C. S.; J. Mater. Sci. 1997, 32, 957.

45. Schoubben, A.; Blasi, P.; Giovagnoli, S.; Nocchetti, M.; Ricci, M.; Perioli, L.; Rossi, C.; Pharm. Res. 2006, 23, 604.

46. Xu, Z. P.; Zeng, H. C.; J. Phys. Chem. B 2001, 105, 1743. 
47. Sebastian, S.; Sundaraganesan, N.; Monoharan, S.; Spectrochim. Acta, Part A 2009, 74, 312.

48. Kloprogge, J. T.; Hickey, L.; Frost, R. L.; J. Raman Spectrosc. 2004, 35, 967.

49. Mateu, B. P.; Hauser, M. T.; Heredia, A.; Gierlinger, N.; Front. Chem. 2016, 4, 10.

50. Ambrogi, V.; Fardella, G.; Grandolini, G.; Perioli, L.; Int. J. Pharm. 2001, 220, 23.

51. Reigosa, M. J.; Pedrol, N.; González, L.; Allelopathy: A Physiological Process with Ecological Implications, vol. 1, $1^{\text {st }}$ ed.; Springer: Dordrecht, 2006.

52. Ambrogi, V.; Perioli, L.; Ricci, M.; Pulcini, L.; Nocchetti, M.; Giovagnoli, S.; Rossi, C.; Microporous Mesoporous Mater. 2008, 115, 405.

53. Tyner, K. M.; Schiffman, S. R.; Giannelis, E. P.; J. Coord. Chem. 2004, 95, 501.

54. Kura, A. U.; Hussein Al Ali, S. H.; Hussein, M. Z.; Fakurazi, S.; Arulselvan, P.; Int. J. Nanomed. 2013, 8, 1103.
55. Passero, L. F. D.; Bonfim-Melo, A.; Corbett, C. E. P.; Laurenti, M. D.; Toyama, M. H.; de Toyama, D. O.; Romoff, P.; Fávero, O. A.; dos Grecco, S. S.; Zalewsky, C. A.; Lago, J. H. G.; Parasitol. Res. 2011, 108, 529.

56. Xu, Z. P.; Niebert, M.; Porazik, K.; Walker, T. L.; Cooper, H. M.; Middelberg, A. P.; Gray, P. P.; Bartlett, P. F.; Lu, G. Q.; J. Controlled Release 2008, 130, 86.

57. Costantino, U.; Ambrogi, V.; Nocchettia, M.; Perioli, L.; Microporous Mesoporous Mater. 2008, 107, 149.

58. Yamamoto, E. S.; Campos, B. L. S.; Jesus, J. A.; Laurenti, M. D.; Ribeiro, S. P.; Kallás, E. G.; Rafael-Fernandes, M.; SantosGomes, G.; Silva, M. S.; Sessa, D. P.; Lago, J. H. G.; Levy, D.; Passero, L. F. D.; PLoS One 2015, 10, 1.

59. Kura, A. U.; Hussein, M. Z.; Fakurazi, S.; Arulselvan, P.; Chem. Cent. J. 2014, 8, 47.

Submitted: October 10, 2018 Published online: January 24, 2019 